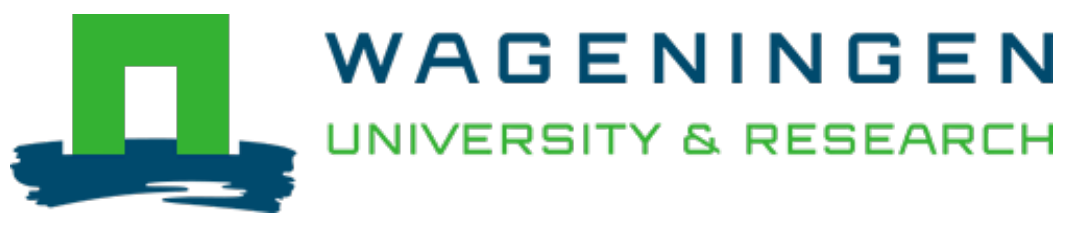

\title{
Powering hydrodiplomacy: How a broader power palette can deepen our understanding of water conflict dynamics
}

\author{
Environmental Science \& Policy \\ Warner, Jeroen; Man, Rens \\ https://doi.org/10.1016/j.envsci.2020.08.015
}

This publication is made publicly available in the institutional repository of Wageningen University and Research, under the terms of article $25 \mathrm{fa}$ of the Dutch Copyright Act, also known as the Amendment Taverne. This has been done with explicit consent by the author.

Article 25 fa states that the author of a short scientific work funded either wholly or partially by Dutch public funds is entitled to make that work publicly available for no consideration following a reasonable period of time after the work was first published, provided that clear reference is made to the source of the first publication of the work.

This publication is distributed under The Association of Universities in the Netherlands (VSNU) 'Article $25 \mathrm{fa}$ implementation' project. In this project research outputs of researchers employed by Dutch Universities that comply with the legal requirements of Article $25 \mathrm{fa}$ of the Dutch Copyright Act are distributed online and free of cost or other barriers in institutional repositories. Research outputs are distributed six months after their first online publication in the original published version and with proper attribution to the source of the original publication.

You are permitted to download and use the publication for personal purposes. All rights remain with the author(s) and / or copyright owner(s) of this work. Any use of the publication or parts of it other than authorised under article $25 \mathrm{fa}$ of the Dutch Copyright act is prohibited. Wageningen University \& Research and the author(s) of this publication shall not be held responsible or liable for any damages resulting from your (re)use of this publication.

For questions regarding the public availability of this publication please contact openscience.library@wur.nl 


\title{
Powering hydrodiplomacy: How a broader power palette can deepen our understanding of water conflict dynamics
}

\author{
Jeroen Warner $^{\mathrm{a}, *}$, Rens de Man ${ }^{\mathrm{b}}$ \\ ${ }^{a}$ Jeroen Warner, Social Sciences Group, Wageningen University, Hollandseweg 1, 6706KN Wageningen, the Netherlands \\ ${ }^{\mathrm{b}}$ Water Governance Consultant, P2, the Netherlands
}

\section{A R T I C L E I N F O}

\section{Keywords:}

Hydrodiplomacy

Power

Negotiation

Negotiation styles

\begin{abstract}
A B S T R A C T
The present contribution argues for taking power in hydrodiplomacy seriously and claims that the hydrodiplomacy literature is too focused on the 'puzzling' of diplomacy at the expense of the 'powering'. Legitimate rule needs a combination of hard (coercion) and soft power (consent). We posit that different styles can be distinguished in negotiation by focusing on the use of power resources. With this understanding, negotiations can be analysed with greater clarity. To transpose the 'powering' and 'puzzling' from the policy sciences to diplomacy, we will draw on the main schools of International Relations theory: Realism, Institutionalism, Constructivism, and Critical theory. Each of them brings insights relevant to different uses of power and in order to understand the negotiations in practice we need all four perspectives. We combine this approach with insights from a particular power typology, and various aspects of time, including uncertainty and path dependency. To exemplify our approach, we draw on a transboundary example involving state and non-state actors (dispute over the use of the Scheldt between The Netherlands and Belgium) and a local example of hydro-political interactions (irrigation system in Yemen). While the Scheldt case appears a good example of a move to common institution building over time, a closer look reveals the influence of "back tables", popular movements and decision-making supported by crises, past traumas and future uncertainties, highlighting the time factor. The Yemeni case illustrates likewise that institutions and better arguments do not necessarily win out while different sources of power are mobilised. We conclude that a focus on institutions, as in the dominant literature, does not tell the whole story in hydrodiplomacy. Our approach enables us in a structured manner to identify additional insights about preferred styles of negotiation.
\end{abstract}

\section{Introduction}

Are analysts using the right analytical frameworks to understand hydrodiplomacy and (transboundary) multi-stakeholder negotiation? One element we will argue that is missing is power. A notable shift has been observed in recent decades from state-to-state diplomacy to a network of state and non-state actors to tackle collective problems in various domains of International Relations, from mobility to human rights and public health. New actors vie for a place at the table or are coopted by state actors to achieve certain objectives and may attempt to mimic established actors in dijongplomacy (Adler Nissen \& Pouliot 2014).

One domain of diplomacy receiving increasing attention in International Relations is transboundary water governance. Transboundary water governance crosses multiple spatial and temporal scales, and water has multiple uses and users. Water however is also highly visible and symbolic ('water is life') and is often bound up with national identity (Hanna and Allouche, 2018), making water an explosive issue when non-water relations are already tense. Since the late 1980s, water wars have been widely predicted, echoed in the 2000s in climate wars. While interstate water wars have failed to break out, water relations are often problematic; especially large infrastructural projects bring tensions and conflicts. Where, collective challenges also motivate cooperative initiatives, their implementation can bring stand-offs, as our cases will illustrate. Engaging in the tricky domain of international water relations, an actor will have to decide what is going to be their strongest suit in terms of the power resources they bring along to achieve their objective.

As observant analysts we will have to live with the given that we have only partial vision on how the diplomatic game is played. Also,

\footnotetext{
* Corresponding author.

E-mail addresses: jeroen.warner@wur.nl (J. Warner), Rens.deman@p2.nl (R. de Man).
} 
what is said or written by public speakers in the arena may be different from their actions on the ground. But what we can observe appears to us as relatively patterned behaviour. In seeking to understanding this diplomatic behaviour, we surmise different 'styles' can be analysed. Some play it rough, others more elegantly; some believe in collaborative teamwork, others are prima donnas or prefer a bystander role. We see the mobilisation of forms of power as central to our understanding of diplomacy. The choice of style of course also depends on their sense of identity, the state of play, who they contend with, what their counterparts (can be expected to) bring. These factors may force them to adopt a suboptimal position compared to their preferred style, but also bring opportunities to be exploited.

Power is a surprisingly underanalysed aspect of water diplomacy. While diplomacy is 'power in practice' (Adler-Nissen and Pouliot, 2014) power is hardly discussed in the (water) diplomacy policy and academic literature. This is strange, as we can clearly observe power play in hydrodiplomatic interactions (as illustrated by our cases). We would not go so far as claim that diplomacy is warfare by other means (though gunboat diplomacy is part of the power arsenal), or that "diplomacy is perceived by an imperial power as a waste of time and prestige and a sign of weakness" (Brooks, 2011), a quote attributed to former United Nations Secretary-General Boutros Ghali. Turning this insight on its head, though, we would argue that power is also never only 'soft' either. Soft power strategies such as persuasion and attraction tend to need the shadow of hard power to be implemented. However, we do not see power as necessarily negative. Rather, we would agree that exercise of power (after Heclo (1974): powering, providing 'power to') is needed to get things done.

Legitimate rule, hegemonic or otherwise, needs a combination of hard (coercion) and soft power (consent). Diplomatic strategy likewise mixes and matches hard and soft power (Hocking, 2005). We will need to understand how power (over, to, with) and power resources are put to use. The exercise of power can have productive (breakthrough) or less productive (veto) outcomes. The present contribution will zoom out to include other approaches to power, as power plays a role even in constructivist approaches.

In this article we claim that different styles can be distinguished in negotiation with particular use of power resources. With this understanding, negotiations can be analysed with greater clarity. In each diplomatic move, forms of power are brought to bear. Their access to and use of these 'power tools' in an episode of interaction (tactics) constitute their 'negotiation style'.

While the hydrodiplomatic literature and course materials tend to take an institutionalist approach, we contend that this approach is only one out of a range of possible, and practiced, avenues. If we analyse diplomatic patterns through the lens of the main International Relations schools, we gain a broader, and we would claim, more realistic palette actors choose from.

Our intuitions, supported by literature, interviews and interactions during the HH9 and HH10 conferences ${ }^{1}$ in The Hague, lead us to expect a reflective understanding of their styles related to the context in use to also be helpful to practitioners of water diplomacy in positioning themselves in future transboundary interactions.

The following propositions, reflecting the challenges we perceive in improving the analytical power of current frameworks, will be elaborated in subsequent sections:

P1 (Section 2) Classical diplomacy and network-based hydrodiplomacy coexist. New forms of network-based and public diplomacy are highly visible, but that does not mean the old ways have disappeared, especially in a 'securitized' issue (Allan and Mirumachi, 2010). Hydrodiplomacy is considered a special kind of diplomacy compared to other

\footnotetext{
1 HH9: (Em)Powering Hydro-diplomacy conference The Hague, 5- 6 October 2018. HH 10: 'The Power of Representation \& the Representation of Power in Water Conflict and Cooperation' 4-5 October 2019
}

new domains of diplomacy as water is a collective action problem, hence requiring the effort of multiple actors 'to get things done'. This brings new actors into the diplomatic realm, such as Non-Governmental Organisations (NGOs) and Transnational Companies (TNCs), who may mimic norms and functions of traditional diplomats (Adler-Nissen and Pouliot, 2014) but bring a fundamentally different dynamic to diplomacy.

P2 (Section 3) The range of power resources used in diplomacy do not command adequate attention. The dominant discourse and literature on hydrodiplomacy tends to be shy of 'hard' power. Current definitions of hydrodiplomacy are not very realistic as they assume the benevolence of the actors to find solutions (Klimes et al., 2019) and build peace on contested water issues and are shy of mentioning power as a key determinant in negotiation. We will argue that this in turn diminishes the effectiveness of tackling a water-related conflict, as important dimensions of a conflict and diplomacy are lost. We will argue that hard and soft forms of power helpfully describe the forms of power used in diplomacy and bargaining between states in the global society of states and contextualize what we see as the 'power gap' in hydro-politics.

P3 (Section 4) Different power sources can be used in chosen negotiation styles. As part of the negotiation, actors can to a degree choose their negotiation style. In international relations (IR) shorthand, these styles roughly translate as realist, institutionalist, constructivist and critical, and each of these styles has their own qualities which are productive in a certain context. This ability to adopt a negotiation style co-depends on the (organization) culture, (power) resources an actor has, the arena it participates in (its position in the hierarchy, Adler-Nissen and Pouliot, 2014) and its own home base ('back-table negotiations').

Our approach for remedying the power blindness we identify is based on International Relations theories. Section 5 combines this approach with insights from a particular power typology, 'power animals'. We add one more element to this framework: time/timing, including the 'shadow of the future' and 'shadow of the past' (Poppo et al., 2008), including the path dependency of diplomatic traditions in particular territories, which may act as 'attractors' to (or repellents from) a particular course of action, and the emergence of 'ripe' moments and windows of opportunity.

Section 6 exemplifies our approach by drawing on a transboundary example and an example of local hydro-political interactions. We conclude the article by reflecting on the cases and propositions and their implications for how power is dealt with in the literature on hydrodiplomacy.

\section{From classical state diplomacy to network diplomacy?}

Attitudes to diplomacy are far from uniform. While American scholarship has long ignored the study of diplomacy and Americans tended to see diplomats as 'untrustworthy figures' (Wiseman, 2011), the English school of International Relations depicts diplomacy as the 'master institution of international relations'. Yet, Criekemans (2010), a Belgian analyst of diplomacy, would claim that the real action appears to be in continental Europe, which has been and still is a nursery for sub-state diplomacy.

Sub-state actors such as federal states, cities, NGOs, may carve out a niche for themselves in the diplomatic arena. Since the late 1990s, the spectrum of diplomatic instruments and the strategies that accompany sub-state entities have become more diverse and complex. In that sense "To a certain extent, today's diplomatic practices resemble a pre-Westphalian world in which realms of different territorial sizes generate their own diplomatic identity and practices [...] diplomacy has become a 'multi-level' endeavour, in which different policy levels (macroregional, national, crossborder, sub-state: regions and cities) each generate specific types of diplomatic activities reflecting specific needs felt at their respective territorial levels." (Criekemans, 2010).

Formally, the state is still the prime mover linking the national and international levels. However, the state may not necessarily be, or want 
to be, the dominant player, and may be outmanoeuvred by non-state actors. States may be intentionally or unintentionally leave gaps and niches for non-state transboundary and sub-state level diplomacy. As a result, diplomacy is starting to look a multi-stakeholder (governance) network in which state and non-state actors perform diplomatic functions. In the 'new diplomacy', "diplomacy is becoming an activity concerned with the creation of networks, embracing a range of state and non-state actors focusing on the management of issues that demand resources over which no single participant possesses a monopoly" (Hocking, 2006: 13).

Sharp (2009) follows Martin Wight's English School which acknowledges three traditions: Hobbesian (might), Lockeian (interests and rights) and Kantian (revolutionary change). Accordingly, he states that: "Diplomacy does not take place simply between states but wherever people live in different groups" (p. 3). It is more than statecraft, but diplomats cannot be reduced to mere operatives in networks of power and influence. People live in groups, in relations of separateness and diplomacy develops to manage these relations. We follow his definition (p. 13): "Diplomacy is, first and last, a set of assumptions, institutions and processes a practice - for handling of certain kinds of relations between human beings".

Non-state and multilateral actors often mimic diplomatic norms, i.e. behaving the way they think state diplomats behave (McConnell et al., 2012; Adler-Nissen and Pouliot, 2014), but bringing a fundamentally different dynamic to diplomatic culture, partly depriving it of its 'culture of exclusivity'. Network diplomacy flattens, but does not eliminate the hierarchy in world relations, "among states but also other kinds of actors as well, and often even a mix of different actors within a single structure of differentiation" (Mattern and Zarakol, 2016).

Since the Peace of Westphalia (1648), diplomacy has been understood as a communication mechanism between sovereign states. The new diplomacy promises transparency, accountability, networking, and inclusion of non-state actors. In the 'new diplomacy' communication is not only between state actors, but actively directed at domestic and international publics to win 'hearts and minds' for a particular agenda or course of action. This means a diversification of publics, and the message sent at different audiences may contain different or even contradictory framings or meet with clashing understandings. In this messaging, the agency (and technology) of non-state actors, both private, civil-society and multilateral, has come to gain considerable influence, and each may piggyback on the other to convey particular narratives to particular audiences. Two-level game theory (Putnam, 1988) and the literature on multitrack diplomacy (e.g. Dore, 2007) likewise call attention to the role of sub-state actors in state-to-state relations.

As a field of practice, hydrodiplomacy has a much longer pedigree than its current rise. For example, state-to-state treaties on the Rhine were concluded in the 19th century, and negotiation, violence and powerplay between states over water precede those. According to Jan Eliasson (2015), deputy Secretary-General of the United Nations 2012-2016, the age of hydrodiplomacy is now upon us. The hydrodiplomacy concept has indeed seen an inexorable rise in recent years (Pohl et al., 2014), with varying interpretations. Yet, while water cooperation is more frequent than violent conflict (Wolf, 1995), many of the world's 310 (2018 figures, in McCracken and Wolf, 2019) transboundary rivers and lakes remain conflictive.

Geography deals different countries different hands. When upstreamers start harnessing the river in infrastructural works, downstreamers start to worry about the upstreamers' ability to cause drought or floods downstream. This makes water a geopolitical resource, unevenly distributed over territories, making it a 'special case' (Giordano, 2003) especially for states in arid areas. As Lowi (1995) noted, upstreamers find it easier to ignore downstreamers. Warner (1992) noted that 'upstreamers use water to get more power, downstreamers use power as leverage to get more water' - although history also has shown a downstreamer like the Netherlands may find themselves at an advantage on issues of navigation and fishing. Downstreamers moreover can mobilise resources, alliances and knowledge as countervailing power resources. Brief, power can be both a tool and a goal.
The interdependencies of water issues with different decisionmaking arenas and geographical and temporal scales make it difficult to steer a water issue towards a certain solution. Drivers for conflict (such as drought, upstream dam construction, pollution) and conflict maintainers (e.g. grievances, current livelihood dependencies) may persist and cause a conflict to erupt and continue; 'conflict escapers' may offer acceptable ways out of conflict for the parties involved.

To deal with uncertainties, people make individual assumptions based on their own interpretation of reality and the knowledge available to them. These individual understandings may create problems when people need to address a common challenge, such as the governance of shared waters. Stakeholders will frame the issue and their interests in it, making (water) conflicts even more complex (de Man, 2016). For Islam and Susskind (2012), this complex nature is even the main problem, increasing the attraction of excluding certain issues or actors.

Complexity increases even more when non-state actors become embroiled in a water conflict. Also, as the cases will show, power voids can create political space for sub-state actors to mobilise their power, whether or not in alternative diplomatic tracks. Part of the reason why many shared water conflicts find themselves in an impasse, is because the conflict transformation process is complex and not well understood ${ }^{2}$ . But another reason for this space may be unwillingness at the interstate level to commit to a deal or its implementation, leading to an active or passive pursuit of a non-decision (Vij et al., 2019). Non-state actors do not have the natural authority to claim a seat at the table but can mobilise their substantive or moral authority or constituency (Meissner, 2005). In each of these cases we should recognise that power matters a great deal, if in different forms.

Finally, a note on scale. Hydrodiplomacy tends to focus on rivers, as managed and negotiated by states. However, Shapland (1997) and Ferragini \& Greco (2005) have concentrated on transboundary aquifer diplomacy. Farnum (2018) moreover claims that we may be focusing on the wrong level when studying hydrodiplomacy by default as dealings between states over rivers and advocates a more diverse scalar focus her own case focuses on sub-state interactions over fog harvesting. We likewise advocate not limiting our analyses to states and rivers. Our Yemen case illustrates a case of sub-state diplomacy on a flood-based irrigation system (ephemeral wadi river) in the absence of a functional national government. In the Scheldt case, transboundary hydrodiplomacy had a multi-stakeholder design and aspects of para-diplomacy ${ }^{3}$

\section{Problems with the hydrodiplomacy discourse}

After an initial 'water wars' scare in the 1990s (e.g. Bulloch and Darwish, 1993), hydro-political literature started to focus on 'water peace'. Likewise, influential hydro-diplomatic literature tends to focus on soft power, from its preoccupation with institutions.

This literature productively embraces the 'new culture' of pluralism, problem-solving and accountability. It believes in creating a level playing field, multi-stakeholder participation, the (rational) power of argument on framing and reframing and developing shared meaning,

\footnotetext{
${ }^{2}$ Interviews in 2015 and 2016 amongst professionals resulted in the identification of the following challenges for hydrodiplomacy: 1) The ability to build trust among competing stakeholders; 2) The ability to organise multi-sector and multi-level interactions; 3) The ability to manage a growing multi-actor policy environment; 4) The ability to deal with uncertainties; 5) Sustainable financing: Transboundary water cooperation is often underfinanced; 6) Sustainable legacy: how to build an enduring capacity among all stakeholders to prevent and resolve conflicts (Huntjens and De Man, 2017)

3 "direct international activity by subnational actors supporting complementing, correcting, duplicating or challenging the nation-state's diplomacy" (Michelmann, H. J. \& Soldatos, P. eds., 1990. Federalism and international relations: the role of subnational units. Oxford: Clarendon Press.)
} 
redolent of Habermasian 'communicative rationality'. Science and technology, a particular strength of the Dutch water sector, are brought in to reduce uncertainties and increasing the solution space. This rational collective problem-solving by multi-stakeholder negotiation, may be summarised as 'puzzling' (Culpepper, 2002).

The going hydrodiplomacy literature reflects this idealist, liberalinternationalist outlook advanced by Woodrow Wilson in the 1910s. In currently popular writings on hydrodiplomacy, power seems only an afterthought. This may be related with the self-image of the discipline. The majority of literature on hydrodiplomacy is remarkably power-shy. Various publications and going definitions consider hydrodiplomacy a type of environmental peace-making. In popular notions such as the $4 \mathrm{i}$ framework (Jarvis and Wolf, 2010) or 'benefit sharing' (Sadoff and Grey, 2002) and the water-food-energy Nexus (Hoff, 2011) we note a tendency to bracket out politics in favour of technical modelling, institutional tinkering, and technical support. This reflects an underlying linear worldview in which interventions lead to improvement. While desirable from an eco-centric perspective, it soon meets a reality check where administrative and eco-systemic scales fail to align (Warner et al., 2014).

Donahue and Johnson (1997) noted that many water conflicts can be understood with respect to crucial differences over what constitutes the primary value of water: water as an economic good, as a political good and as a cultural good. Yet, because water is so symbolic, it can easily become a focal point for non-water conflicts, such as identity politics (Pohl et al., 2014). When threats are being made over water, there is often a non-water history (land claims, grievances, political rivalry) that fuels it, while water also attracts the attention of external actors like donors, e.g. on the Nile, making it beneficial to play water conflict up (Warner, 2012). Also, puzzling may obscure or negate the overhang of covert conflicts (e.g. the 'shadow of the past') that may suddenly erupt, and surprise diplomats involved.

Hence, we need to carefully consider aspects which may not be immediately visible through a puzzling approach. All these forms of puzzling are helpful (e.g. where political relations have broken down), increasing the solution space by 'empowering knowledge', but will not get us anywhere without powering: the wherewithal to get things done, to mobilise support and buy-in. While puzzling may identify the best option based on best knowledge, the best option is not necessarily the most feasible option. In the end, the result of strenuous puzzling does need 'powering' to make it happen (e.g. De Man, 2016). Nothing goes without the judicious use of power in hydrodiplomacy to get things done, or not to get things done.

In our terms, borrowed from Heclo (1974), we not only argue that the popularity of 'puzzling' obscures that powerplay hasn't fallen out of practice, but also that it has its uses for certain actors at certain moments - puzzling and powering go in tandem. We would argue, then, that power is central to diplomacy, not just an aside.

It is certainly true that 'new diplomacy' emphasises transparency and networked governance. We believe however that Ruggie (2005) was on to something when claiming the 'old' and the 'new' culture of international diplomacy are living side by side in today's diplomatic practice. The 'old diplomacy', as practiced during, say, the Concert of Vienna and throughout the Cold War, was characterised by exclusivity, secrecy and self-interested powerplay. Even when one is loath to use hard power, the actual outcome of a situation depends also on the power sources of other actors. Broadening the base brings in a broader palette of diplomatic tools and strategies, from outright confrontation to initiating multilateral initiatives, or, as the TWINS model (Mirumachi and Allan, 2007) suggests, a mix of conflictive and cooperative moves.

This impels us to broaden the usual understanding of conflict and power. Not only because even if one's own intentions are pure, one should be prepared for others that are not; conflict can be productive by making interests explicit which cooperation may obscure, while power can be the sine qua non of deal making. We argue that adding other concepts of power and diplomacy add to the analytical depth as they jointly paint a fuller picture of the range of actual interactions. To expose the underlying world views of current analysis and prescription is not to say it is wrong, and that another view is essentially right. As Menga (2016) notes, theories of International Relations should not isolate but converse with each other (see Stucki, 2005, Julien, 2013 and Warner, 2012 for such multi-focal approaches in transboundary hydro-politics). We will argue this approach in the next section.

\section{A broader palette: the four main schools of IR}

To transpose the 'powering' and 'puzzling' from the policy sciences to diplomacy, we will draw on the main schools of International Relations theory. In the study of International Relations four paradigms are generally identified: Realism, Institutionalism, Constructivism, and Critical theory (Viotti and Kauppi, 2019 [1991]). The different schools, and sub-schools have different preferences on what are the building blocks of international relations. Actors, interests, rules/institutions, discourses and resources are frequently advanced, if in different permutations and conceptualisations, though not mutually exclusive. While adherents of one often ignore the other three paradigms, each of them brings particularly useful insights relevant to different uses of power. In order to understand the negotiations in practice we need all four.

a. Realism: "We respect a treaty as long as we expect to benefit from it"

For (neo)Realists, students of Realpolitik, diplomacy is the instrument by which actors attempt to achieve their aims, in relation to those of others. It presumes a state-centric world, seeking stability in a context of global anarchy but rejecting interdependence. Power asymmetry is considered productive and game theory helps determine a coordination strategy where communication is lacking. The transactional 'old culture of diplomacy' Ruggie (2005) relates to is close to a classical Realist approach to International Relations. Inspired by classical European statecraft and adopted by US Cold War statesmen like Henry Kissinger, it sees 'might' as right, the state as the prime mover, and hard power assets (force, coercion and intelligence) and stability as its key objectives. Realists see diplomacy as a 'more palatable form of force' to be brought to bear in the national interest (Kissinger, 1995). Criekemans (2010) notes that in recent times, emergent powers such as China or Brazil have 'used diplomacy to 'test' their relationship vis-a-vis each other and, more importantly vis-a-vis the hegemon, the United States of America and we would add, the US under Trump seems to be acting much the same.

For Realists, water normally isn't 'high politics'. A Realist mind-set will raise the bar pretty high before bringing water on board in diplomatic interactions. Water and environment may be relegated to technical issues, which also reduces political accountability for agreements with far-reaching consequences. Still, in hydro-politics states purse actions such as unilateral dam building or diversion and proxy war that may be labelled 'Realist'.

b. Institutionalism: "A treaty is better than no treaty at all"

For institutionalists, the key elements are creating value and building trust as the key elements in a presumed level playing field. They look for linkages and institutions for collective action that can cushion against destabilising shocks and promote regional integration. This school of thought is functionalist (looking for the perfect 'fit' for problem-solving) and does not assume the state is the only or even key actor. Complex interdependence brings multiple centres of authority (polycentricity) and opens the door for other transboundary interactions to tackle shared water issues as an alternative to 'high politics' through 'multilevel diplomacy ${ }^{4}$. Many international policy fields are believed to be structured in terms of 'international regimes' governing an issue-area -

\footnotetext{
${ }^{4}$ Tracks 1.5/2/3/4 are shorthand for alternative diplomatic channels when formal government-to-government diplomacy has broken down, paving the way or serving as an alternative avenue for a resumption of negotiation.
} 
norms, procedures, practices (Krasner, 1983) or patterned behaviour (Puchala and Hopkins, 1982). These issue-areas may also be described as transboundary policy arrangements - a set of rules, resources and discourses (De Jong, 2000; Barnes-Dabban et al. (2018).

The creation of institutions and regimes is believed to help structure international behaviour, promoting complex interdependence. Complex interdependence between states will then reduce chances of future warfare, creating stability of expectations (lengthening the 'shadow of the future', Axelrod and Keohane (1985)) and reducing the prominence of the state and the attraction of independent 'going it alone'.

Institutionalism sets great store by law and norm creation and in so doing contributes to 'eroding the effect of power and hegemony on international agreements' (Gupta, 2016). Domestic and international politics may spill over into each other. The national policy arena (the 'back table') however may well be characterised by a different set of rules, resources and discourses than the international chessboard. Individual actors may decide, or be persuaded, to conform or ignore the norms governing the decision-making arena. This discrepancy between the levels is, to a degree, found in the Scheldt case discussed below.

Contrary to Realists, institutionalists do not assume the state to be the leading and unitary actor. It takes a network perspective of International Relations, in which different sub-state actors may compete or form competing alliances, e.g. the Dutch Environmental Ministry may ally with other European Environmental Ministries to provide a counterweight to the dominance of agricultural ministries - or federal states or cities may conduct their own diplomacy, co-opted or contradicted by central government actors (see Scheldt case).

c. Constructivism: "A treaty is based on shared problem perception "

The constructivist paradigm sees co-operation and conflict not as outcomes of power calculus underpinned by material resources but related to identity (Jarvis and Wolf, 2010). Power relations are underpinned by normative or ideational structures and actors engaging in social interaction and interplay to bridge perceptual gaps. Knowledge and ideas are important power resources here. Key examples in the environmental domain are the Stockholm treaty and the Plan Bleu to clean up the Mediterranean (Haas, 1990). The common understanding of a joint challenge is shaped, often led by members of an epistemic community. Scientists, currently most visibly IPCC, consciously use the power to shape the terms in which the problem is understood to trigger ('power') collective action, mobilising 'power with' rather than 'power to' or 'power over'.

This analytical tradition is like a sociology of relationships in International Relations (Wendt, 1999) where states have identities and personalities: they want to be liked or feared and may learn from experience. They may redefine their identities and interests such that they redefine their relations with other actors. Frustrated, ontologically (existentially) insecure states may consider it beneficial spreading chaos, and therefore thwart water cooperation (Mitzen, 2006). Other states may seek to endeavour to change this state's 'self-image' to get them back to the negotiating table.

d. Critical theory: "Cooperation negates structural inequalities"

While much of the governance and diplomacy literature suggests that everyone is equal or has an equal opportunity to make the best argument prevail, there is always the 'shadow of hierarchy' (Jessop, 2002). Material resources matter in the international arena. As Foucault noted (see Heller, 1996), there is no power without resistance, no hegemony without counter-hegemony. Critical theory is well placed in promoting an understanding of resistance to seemingly collaborative, win-win type agreements. Critical theory purports to look beyond the interests of the elites characterising diplomacy, and indeed are the basis for all four types of elite power in Scott's typology (see below). But non-rulers, the subaltern, may wrest hard and soft power from the hands of that elite and make other means of coercion, inducements, authority, expertise count. The Cuban, Venezuelan, Bolivian and Uruguayan governments purported to revolutionise the right to water at a global level ${ }^{5}$ and in the 4th World Water Forum in Mexico (2006), while elsewhere global social and environmental movements operate with this goal.

While Ritchie and Egeland (2018) mainly consider the resistance of some states to the hegemony of others, we may also scrutinise resistance or norm transformation by non-state actors. This resistance not only takes place through institutionalist strategies such as (influencing) norm creation (Haufler, 1993) and forum shopping (von Benda-Beckmann, 1981). It can also take the form of extra-parliamentary action to seek entry to the diplomatic playing field or to undermine the legitimacy of formal processes (Scott, 1985). This might extend to combining collaborative strategies within the arena with adversarial strategies outside the arena to address perceived iniquities. For the radical/critical school, finally, power, and especially power difference, is core to the approach. It focuses on exposing, analysing and resisting exploitation and dependency, arguing the playing field is never level, and seeks to identify transformational alternatives and empower social actors to attain them. The power may not be visible but structural, so that our analysis should drive at the root causes. The last column in the below Table 1 lists the key drivers for changing power positions according to the four schools ${ }^{6}$.

\section{e. Power sources}

As diplomatic actors enter the negotiation arena, they 'take' different sources of power with them, they can mobilise in the interaction with the other actors. Given the role diplomacy has often played as an alternative channel to warfare, diplomacy itself tends to be considered 'soft (i.e. noncoercive) power'. Not only would we argue that diplomatic arm-wrestling can be experienced as pretty coercive, however, we also note that hard power (threats and inducements) is part and parcel of international relations.

Political science has produced countless theories and typologies of power, all intensely debated. Our choice of framework draws on the sociologist John P. Scott (2001, 2008) who, after Max Weber, sees power as the capacity to affect others, as 'the production of social effects'. Scott identified four disciplines, metaphorically represented by four 'power animals' that dominate power elites in particular political settings. While he identified the forms of power they carry (coercive, financial,

Table 1

Four IR views of changing power positions.

\begin{tabular}{lll}
\hline $\begin{array}{l}\text { School of } \\
\text { thought }\end{array}$ & View of treaty & Force of change \\
\hline Realist & $\begin{array}{l}\text { We respect a treaty as long as we } \\
\text { expect to benefit from it } \\
\text { A treaty is better than no treaty at all }\end{array}$ & $\begin{array}{l}\text { Change in material } \\
\text { power position } \\
\text { Changing cost- } \\
\text { benefit ratio } \\
\text { (assessment) } \\
\text { Constitutionalist }\end{array}$ \\
Critical & $\begin{array}{l}\text { A treaty is based on shared problem } \\
\text { perception and facts (different from } \\
\text { material interests) } \\
\text { Multilateral treaties institutionalise } \\
\text { manufactured 'common sense' and } \\
\text { structural inequalities }\end{array}$ & $\begin{array}{l}\text { Changing concept of } \\
\text { control; resistance }\end{array}$ \\
\hline
\end{tabular}

\footnotetext{
${ }^{5}$ Bolivia, Venezuela, Cuba \& Uruguay, Declaracion complementaria en el Marco del IV Foro Mundial del Agua [Complementary Declaration of the Fourth World Water Forum], 22 March 2006

${ }^{6}$ Different schools also have different conceptualisations of what the arena itself is like, which would technically require four different arena representations as well. We will for now leave this outside the scope of the present contribution.
} 
authoritative, cognitive) in a domestic context, we argue that these forms of power also helpfully describe the forms of powers dominating diplomacy and bargaining between states. As others in the arena may use or be open to different sources of power, we may surmise diplomatic services are well advised to compose multidisciplinary teams when dealing with their diplomatic interlocutors from other nation-states, and deciding which form of power would, could or should dominate proceedings.

Among these power resources, hard power is represented by the lion (strength, threat of violence, coercion, physical force) and the fox (cunning, offering inducements such as side payments). Machiavelli (1952: 69) noted that leaders have to be like lions as well as foxes, as the lion is defenceless against traps, and the fox is defenceless against wolves - which also highlights the situatedness of apt power resources. Both can change the structure of constraints with a view to inducing conformity of conduct with goals desired by the actor exercising power.

Soft power comprises the powers of the bear (authority, command, rules and institutions, treaties) and the owl (wisdom, knowledge, expertise). Modes of Alternative Dispute Resolution such as mediation rely on the power of argument (Gazal-Ayal \& Perry 2014), on recognising interests rather than position (Fisher et al., 2011). While Scott relates these to (domestic) elites, we can also imagine them as the power base of diplomacy. Dependent on the goals and context, a diplomatic actor will emphasise one of those power varieties, and if necessary mobilise professionals (which we will consider 'resources' for the sake of the argument) within or outside the diplomatic force that can 'power' the strategy: in COP climate negotiations we expect a country to bring experts to further 'Nexus' goals, maybe buttressed by financial incentives (carrots) or sanctions (sticks) rather than military threats, while on water in historically disputed territory, water expertise may be far less salient. However, a state with identity issues may prefer a coercive strategy on everything (Table 2).

\section{f. Negotiation styles}

The above types of power may align to a higher or lower degree with rationalist/functionalist strategic approaches to International Relations: what is the best fit to situation and goals. We have also seen that states may ignore or thwart other states (realism), may not speak with one voice (institutionalism), may have identity issues but also change their interest perception (constructivism) or be a front for structural power inequalities that may erupt and destabilise or revolutionise the ruling elite (critical theory) $)^{7}$. The 'multiple personalities' hiding behind the united front may not align and may be schizophrenically (or pragmatically) deployed. There isn't always a coherent 'method to the madness'. Each of the 'animals' may dominate at any one time, though mixes are certainly possible, and patterns may be observed that become characteristic of the actor's 'negotiation style'.

The ability to choose a negotiation style is depending on the

Table 2

Four types of power.

\begin{tabular}{llll}
\hline & Style & Instrument & Mascot \\
\hline $\begin{array}{c}\text { Corrective } \\
\text { (hard power) }\end{array}$ & Coercion & Force. Restricting other's action scope & Lion \\
& Inducement & $\begin{array}{l}\text { Incentives, manipulation of access to } \\
\text { resources, costs and benefits, e.g. side } \\
\text { payments (Dinar, 2006) } \\
\text { (Specialised) knowledge }\end{array}$ & Fox \\
$\begin{array}{c}\text { Persuasive } \\
\text { (soft power) }\end{array}$ & Expertise & Owl \\
\hline
\end{tabular}

\footnotetext{
${ }^{7}$ An 'owl' as the voice of science would be expected in constructivist environmental treaty making, but may also rationalise Realist geopoliticking (game theorists).
}

(organization) culture, (power) resources an actor has, the arena it participates in (determining its position/ hierarchy) and its own home base (back table negotiations). Meerts (2014) notes: "Power and influence create boundaries for the weak and remove them for the strong. Yet power and influence are not only structural, but also situational. The question is not only what the resources are, where they are and who is controlling them, but also how they are dealt with in the process needed to go from $A$ to $B$, and how they are influenced by that process. " This is to a degree bound up with cultures and personalities, but also with strategy. By identifying the paradigms in negotiations, we are able to identify the sources of power and hence to deepen the "flat" character of the power animals.

Below we will describe the episodes in a transboundary water conflict as rounds in a boxing match or the moves in a chess board game, part of a longer match. Bringing in the time element, we can consider multiple rounds of negotiation (Teisman, 2000) where actors make decisions in multiple rounds of interaction. Rather than one actor bringing a solution, various courses of actions may be proposed by various actors in pursuit of various goals, which may change over time. These actors, strategies and goals find themselves in multiple rounds of bargaining. Multiple chessboards may be at play which may be coupled (e.g. the Rhine, Scheldt and Meuse).

The 'shadow of the future' (uncertainty, e.g. climate change) and 'shadow of the past' (overhang of perceived 'wrongs' or slights in the past) are attractors for behaviour. Path dependencies also shape diplomatic culture over time.

Temporising (speeding up or slowing down) is biding one's time waiting for the 'right moment' to act when a new more amenable counterpart comes around, or a time when unwelcome messages or actions are likely to be drowned out by other news (Warner and van Buuren, 2016). Successful diplomacy is often said to depend on' ripe moments' (Zartman, 2001); actors may rush to take advantage of a window of opportunity before it closes. Political or administrative crisis mode provide such ripe moments. The ripe moment arises when parties discuss what they want to resolve: the moment when a stalemate becomes mutually hurting and attrition sets in. Sudden disasters may also provide them (Kreutz, 2012), although such windows in 'disaster-diplomacy 'tend to accelerate emerging trends rather than create entirely new situations (Kelman, 2007). Ripeness should be matched by a readiness of 'credible people to begin talks about reframing the problems' (Jones, 2017: 18).

The figure below summarises the conceptual framework. The figure schematically depicts a diplomatic actor (centre rings in blue) entering a negotiation arena (outer rings in green). The negotiation arena consists of the 'other actors'. The perceptions and type of power sources applied are indicated through stars pointing to the corresponding ring. We differentiate between different 'rounds' in which the interaction takes place. Each round is consistent in style. Hence, we can visualise how styles change through time through interactions between the diplomatic actors but also through external shocks (as will be demonstrated through the Scheldt case) (Fig. 1).

\section{Case study analysis}

To exemplify our approach, we draw on a transboundary example (Scheldt) and a local example (Yemen) of hydro-political interactions.

\section{The Scheldt estuary case}

The Scheldt case is a case in point, both in terms of the broadening actor base in hydrodiplomacy, and a palpable oscillation between

\footnotetext{
${ }^{8}$ The Scheldt (Escaut) originates in the Northwest of France before it enters Belgian territory at Tournai (Doornik). While France has had some disputes with Belgium over the Scheldt, most recently over pollution in 2020 (Strauss and de La Hamaide, 2020), the river is not central to French concerns. Since co-signing the Scheldt Agreement in 1994, French has hardly spoken out about the river. The key transboundary conflict dynamics has been over the river Scheldt estuary, shared by the Dutch and Belgian coriparians.
} 


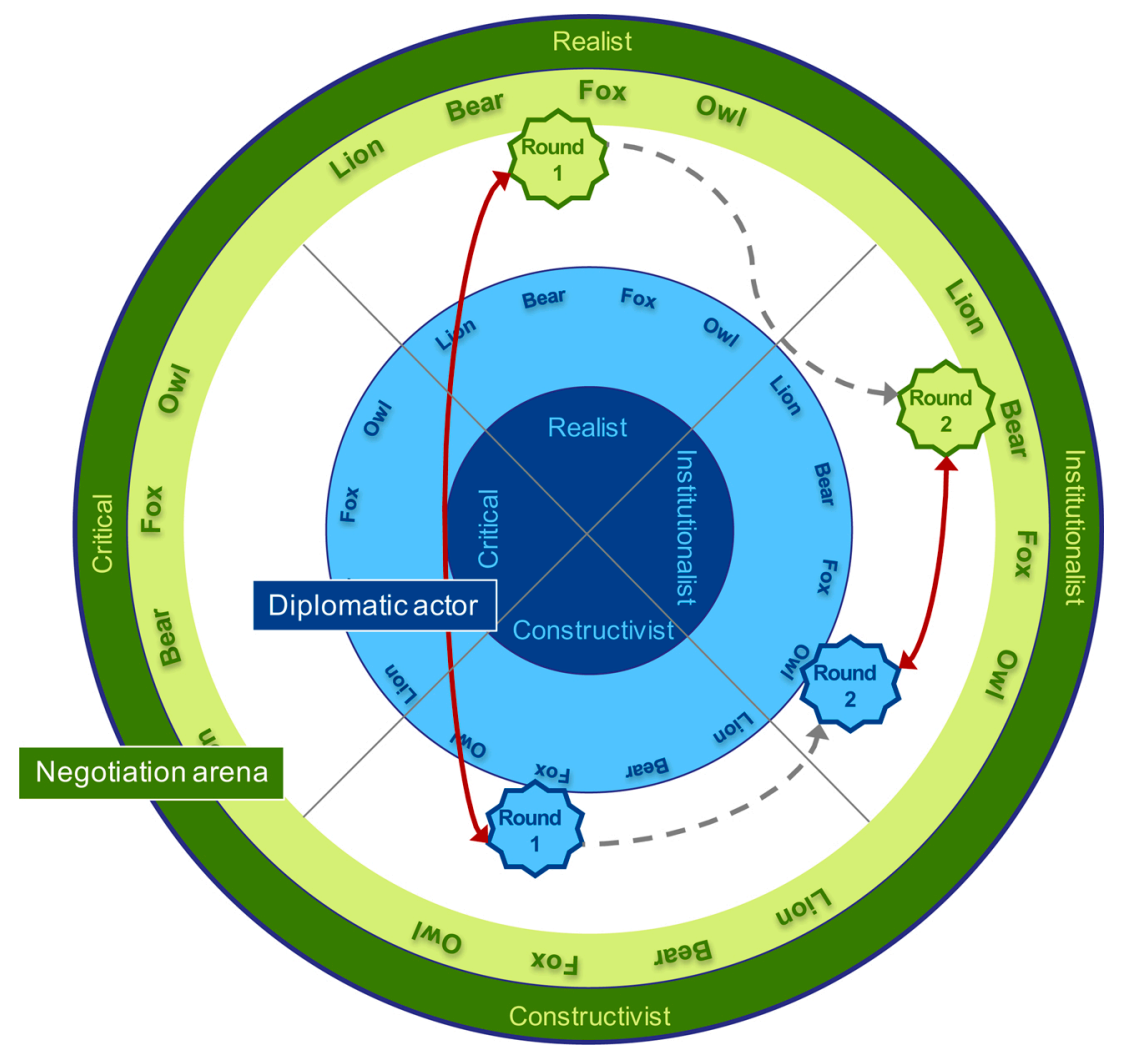

Fig. 1. Schematic overview of the application of the conceptual framework.

various negotiation styles, which we will analyse through the prism of Dutch hydrodiplomacy ${ }^{9}$. Both basins have a long history of powerplay and litigation before environmental river rehabilitation goals formed an important part of multilateral deals arrived at in the late 20th century. A multiplicity of sub-state actors (the Flemish authorities; Antwerp's port authorities; environmentalist NGOs) was allowed to play a role in pressing for maintaining the natural beauty of the Scheldt in the face of deepening the river's fairway desired by the Flemish.

However, in both cases domestic interests fearing damage reared their heads and persuaded the national government to change tack. A relative domestic power void in the early 2000s had enabled parochial interests to hijack international negotiations. After a centre-right coalition took power the Dutch started to play hardball with Realist armtwisting on both basins around 2010, powerplay defeating institutional weakness. This delayed the implementation of transboundary agreements on both rivers and risking total breakdown until the European Commissioner stepped in threatening punitive measures.

\section{The rounds:}

Round 1:

The Netherlands has taken advantage of its geography in navigation, chaining the harbour in the 17th and 18th century then levying toll on the river Scheldt in the 19th).

In Realism hard power dominates (lion - coercion) expressed in blockades, toll levy, lawsuits, negative linkage politics. In 1648 the Dutch won the right to materially close the Scheldt so that Rotterdam could thrive 'as grass grew in the streets of Antwerp' (George, 1927). In its struggle for emancipation from the Dutch in the 19th century, Belgium mobilised the support of Great Britain, a global Great Power at the time, which as a strong naval and commercial power stood to benefit from promoting free navigation. After Belgian independence the Dutch

\footnotetext{
9 This means backgrounding of less prominent players in both cases. The cases seek to illustrate rather than to be comprehensive
}

maintained the right to levy toll. Unsurprisingly, describing Belgium's diplomatic style after independence, Helmreich (2019) identifies a 'willingness to resort to arms', a belligerence resonating even today. We can thus note a Realist mindset on both sides: The Netherlands also has proved not to be above Realist powerplay through shifting alliances, while the Belgians were willing to fight fire with fire. After Belgian independence, the Belgians set out to develop the Antwerp harbour.

But the Dutch dragged their feet each time the Belgians requested something they needed Dutch cooperation for deepening the Scheldt, and applied linkage politics encumbering a Scheldt treaty (Meijerink, 2008) until the federalisation of Belgium in 1993 enabled it, making Flanders and Walloon separate diplomatic entities.

Round 2:

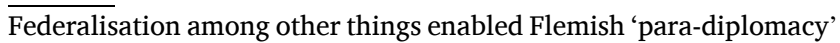
with the Netherlands for the Scheldt estuary visioning without Walloon meddling (Criekemans, 2006). But another actor took the stage: Dutch and Flemish environmental NGOs who, mimicking state diplomacy, in 1997 signed the Saeftinge treaty. As 'constructivist owls', their gesture helped the Dutch and Flemish state actors reinterpret their stance, and to engage in a visioning process for the Scheldt estuary. They signed a collaborative memorandum in 2001. Led by environmentalist NGOs a host of non-state actors came together under the supportive but hands-off binational aegis. Dutch and Flemish knowledge institutes supported joint fact finding on the consequences of deepening for natural values. But a long previous history of Dutch hegemony cast a "shadow of the past" on Belgium which continued their view of Dutch as imposing and insensitive, looming over negotiations. When the well-liked Dutch co-chair sadly died in a car accident however, this shock triggered a will to honour his effort with an agreement. It was a ripe moment propelling participants to action, leading to a deal in 2005. A deal between the harbour and NGOs on a more sustainable way of fairway dredging provided the breakthrough (owl) (van Buuren and Warner, 2009; Verhallen and van Densen, 2012).

\section{Round 3:}


From 2008, and especially in 2010-11 the Netherlands returned to Realism as Dutch leaders tried to duck their international responsibilities under populist domestic pressure, leading to an escalating row with both Scheldt riparian states. Local protest against the flooding of adjacent Dutch and Flemish polders under the 2005 deal were successfully 'upscaled' to the national political level in the Netherlands. Angry missives from Flanders met with Dutch promises for 'more research into alternatives' as apparent delay tactics. The Flemish then threatened retaliation in non-water domains. Rapped on the knuckles by the European Commission and aware of reputational risk abroad, the Dutch eventually demurred (Warner and van Buuren, 2016). A new domestic governing coalition saved the day getting the Dutch back in line steering towards implementation of the Scheldt agreement. Silent international cooperation (successful countervailing power) ensured long-term co-riparian trust. Belgium and the Netherlands' common European Union membership had provided a brake on Dutch "rogue" action.

Table 3 below summarises the rounds and reveals presumed 'power animals'

The Scheldt case is illustrated through the overview presented earlier. For reasons of readability, only round 2 and the start of round 3 are depicted. In this overview the interactions between Belgium, The Netherlands and the NGOs are visualised. In round 2, the interaction between the parties is influenced through the sad loss of the co-chair. In round 3 the Netherlands has come under pressure to change its position, leading to a repositioning of the other parties at the table (Fig. 2).

II. Local power play in Yemen (short case)

Research in Yemen (by Huntjens and De Man, 2014) on the effectiveness of conflict resolution in water conflicts prior 2014 draws attention to the role of power and the use of legal pluralism in a number of water conflicts playing out as the central state keeps failing. The tribal structure strongly affects the implementation of legislation and the way conflicts are dealt with. Through former President Saleh's patronage system, a political elite gained control over water resources through financial power at the expense of the rural poor. The legal system in Yemen is pluriform and disjointed: contradictions exist between the various sources and legal references, such as sources of pre-Islamic, sharia and formal law. Legal pluralism allows powerful newcomers to deviate from customary rules.

Round 1: Realist-Lion

As in Yemen the state failed, existing agents are incapable of creating stability as they lack hard power assets. In this context new actors can do what they want. One of these cases concerns a water conflict as a result of a newcomer buying land upstream in an existing irrigated area. This newcomer changed the scene since 2004 by imposing a material barrier, a gate, hence allowing him to use the upstream irrigation water for his own purpose. His action ran counter to the customary rules of prior appropriation.

As a result of the blockage, the canal irrigates a much smaller area than the original 1000 ha and several downstream farmers haven't been able to irrigate their lands since. These farmers have no other choice but to rely on very expensive groundwater as the diesel price for the diesel pumps skyrocketed after the 2011 revolution. Several farmers did not have any choice but to leave for Saudi Arabia to find a job.

Round 2: Institutionalist-Owl

As the water conflict relates to an irrigation structure, farmers turn to the irrigation agency to solve the conflict. The irrigation agency was the sole organization to take some initiative to solve the conflict by proposing technical alternatives, but the newcomer boycotted all those. The agency could not procure any help to force the person into cooperation either, although sometimes it requested the help of local wise men.

Round 3: Realist-Bear

As the irrigation agency was unable to settle the conflict in 2006, a well-respected sheikh forced the offender into cooperation - or else face consequences.

Round 4: Realist-Bear, but with weak authority

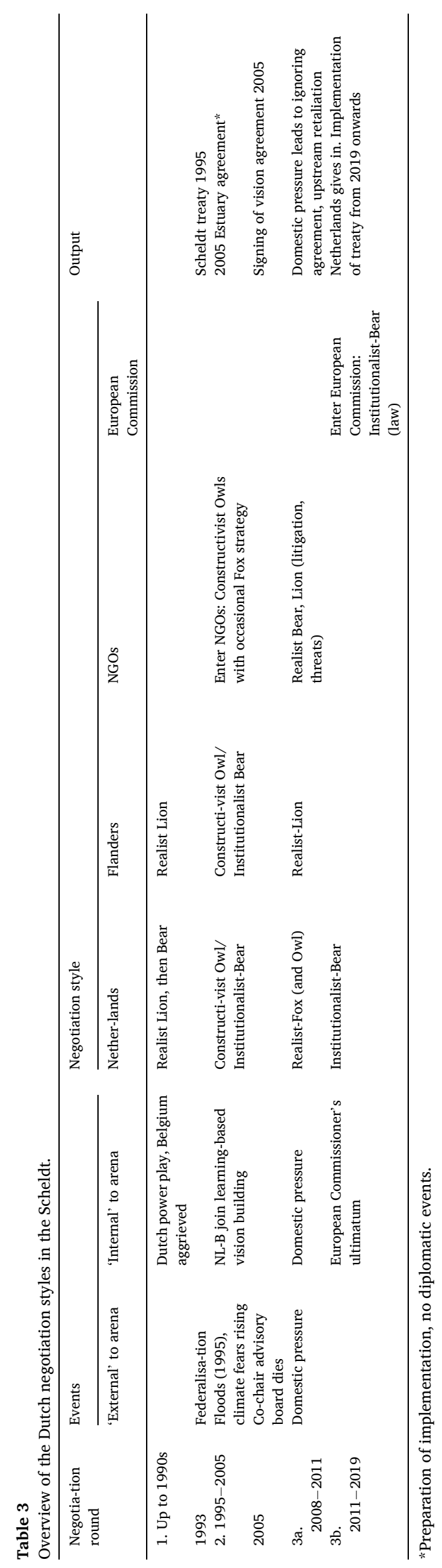




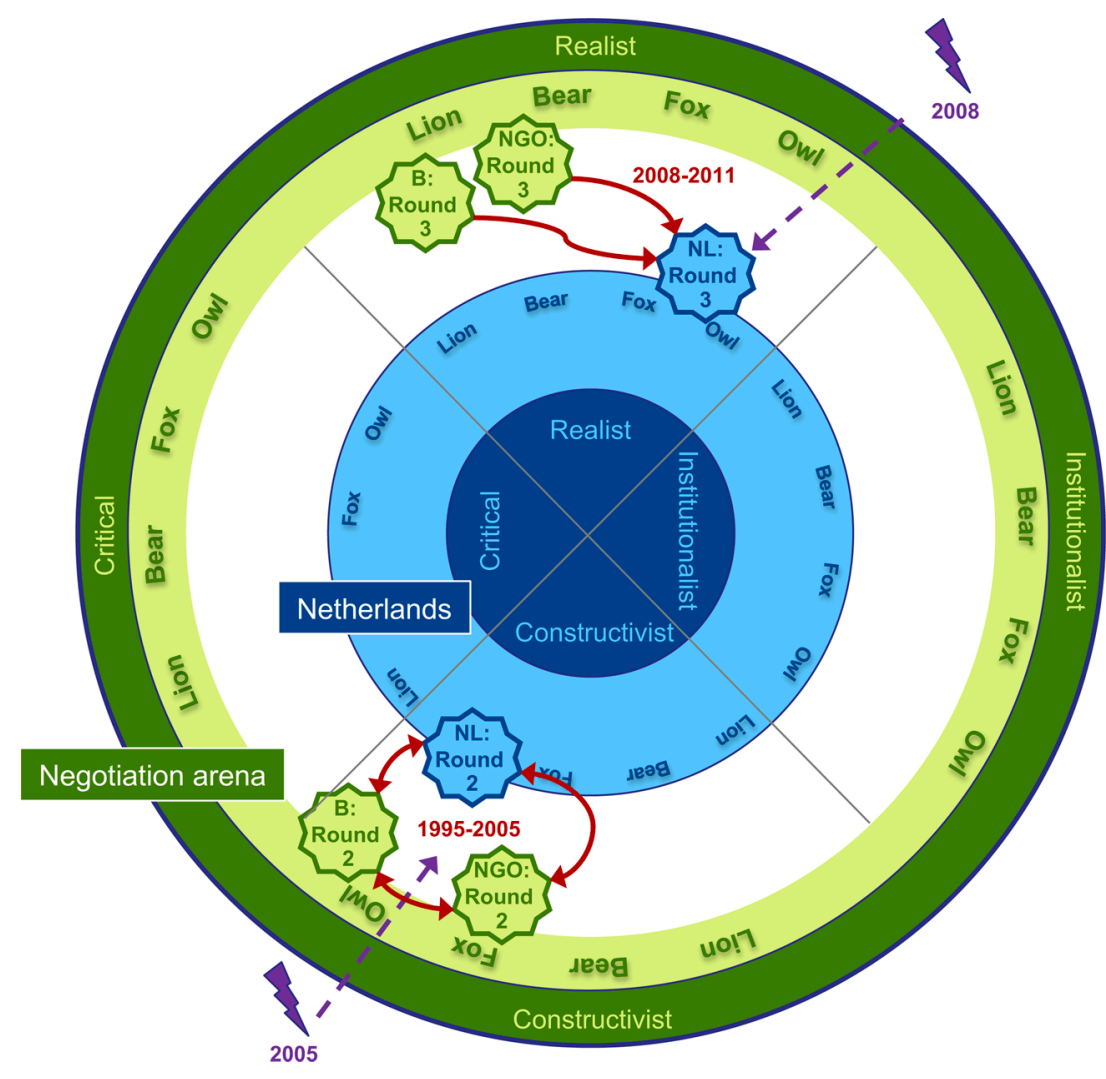

Fig. 2. Schematic overview of the power positions in Scheldt hdyrodiplomacy rounds 2 and 3.

However, after the sheikh's death in 2010, his son took over, but he lacks his father's authority, and despite the agreement, the offender started blocking the stream again.

Round 5a: Institutionalist-Bear

Since the district government also bears a role in settling disputes around water, the affected farmers and the agency submitted a formal complaint to the district director in 2010 to resolve the situation and get the newcomer to cooperate. Despite this, no action is taken, as the offender is powerful.

\section{Round 5b: Institutionalist-Bear}

The person, a contractor, is well-connected with influential people in the government and security who back him up. He uses his resources to maximise his control of the water. The transitional period since 2011 contributed to the continuation of this situation as government's influence has grown even weaker. Powerful landowners wield great influence on water allocations and by cutting off floodwater from smallholders they aim at pressuring them to sell their land at a low price.

\section{Round 5c: Institutionalist-Bear}

Appealing to the court also seemed not an option for local farmers, who pointed out that the court does not have a "very good reputation" in the area. Affected landowners asked neighbours for their support (mobilising "power with"), but they lacked the required social power and were too afraid of retaliations.

In this case various forms of power were used to exercise control over water and settle the water conflict. This case seems to support the need for neo-institutional strengthening, however, to achieve this counterpower will need to be organised to defeat the power of the lion and fox. Downstream landowners avail of no salient sources of power.

Huntjens and De Man looked into the development of mobile water courts for water related conflicts. Mobile courts have been recommended before and are corruption prone. Next to court rulings, these mobile courts should provide education (owls) on the applicable laws and provide technical advice in relation to water issues, thereby facilitating conflict resolution outside the courts. In this manner the gap between formal law and traditional law could be bridged and the legitimacy of the court rules improved, making justice accessible even for the most disadvantaged groups. Mobility also has the advantage that political-economic connections of a 'crony capitalist nature' (that provide opportunities for rule, self-enrichment and prestige) have less impact on the objectivity and legitimacy on court rulings ('anti-fox' countermeasures).

\section{Discussion and conclusions}

In the present contribution we have argued that current hydrodiplomacy literature is too focused on the 'puzzling' of diplomacy at the expense of the 'powering'. Next, we have posited that different styles can be distinguished in negotiation by focusing on the use of power resources.

The cases illustrate that a focus on institutions, symbolised by the 'Institutionalist-Bear' (authority-based) negotiation style, does not tell the whole story in hydrodiplomacy. Fledgling institutions can be tested and counteracted (Scheldt case) or even swept aside (Yemen case). By focusing on the different styles in the analysed cases we gained additional insights about how power was used in these real-world negotiations in practice. Therefore, we consider the framework a promising tool in obtaining a different insight into diplomacy and power by covering a broader power spectrum, at the transboundary but also substate level.

We could have illustrated this by starker instances - one reason why, for example, the Kingdom of Lesotho has not made a noise about the meagre South African royalties it receives for its water exports (through the Lesotho Highlands Project), although the 1986 protocol expressly enables a 12-year agreement revision cycle, may well be the memory of South African's 1998 incursion (i.e. hard power) into Lesotho safeguard water for its economic powerhouse (Gauteng province) at a time of political turbulence in its neighbour state (Meissner and Warner, 2017). Old-school Realism explains the status quo much better than does the 'new diplomacy', supporting proposition one. Treaties or 
non-engagement do not exclude proxy warfare or obstruction.

With the apparent breakdown of the World Trade Organisation and the rise of illiberal nationalist democracies, diplomatic mores seem to be hardening, in a move from rule-based to power-based bargaining (see also Suri, 2019). The American withdrawal from climate agreements suggests this also affects environmental diplomacy.

Many hydrodiplomacy cases obviously do not go that far. But the framework we have shown enables us the ability to identify the dynamics in power positions in time between the parties involved in a water related conflict. With this understanding, negotiations can be analysed with greater clarity.

Take the Scheldt estuary case' dynamics. The prevailing discourse in hydrodiplomacy is reflected in the Dutch professed self-image of a noncoercive 'Dutch approach' emphasising institution- and knowledge building (van Genderen and Rood, 2011). Zooming out to a centennial scale, the Scheldt case appears a good example of a move from Realpolitik to common institution building. But zooming in, we see telling centrifugal moments.

A prevailing institutionalist discourse, which in the Dutch case maps onto its self-professed diplomatic culture and non-coercive 'Dutch approach'. arm-twisting is not ruled out, but more likely to happen behind closed doors as public diplomacy, especially in water, emphasises institutions and knowledge (van Genderen and Rood, 2011). Building on its legalist history (from Grotius on), the Netherlands reckons a small country stands to benefit from treaties and its membership of Benelux and European Union. The Netherlands government has however used diverse sources of power crisis windows on the Scheldt, changing tack over time, sometimes strategically, sometimes responding to a change in the domestic power base.

The 1990s had seen a knowledge-dominated stage on the Scheldt bringing a different framing of interests (proposition three), as crises created 'ripe moments' for joint action. Research to tackle 'wicked problems' depoliticised the issue by forging an agreement on concepts and a baseline. Common 'shadow of the future' challenges requiring joint action, such as fears of climate-induced sea level rise, would seem to make this a herald of the diplomacy of the future. But fears of the future did not erase the 'shadow of the past' going back centuries hence we should not be surprised other basins being beset by more recent historic traumas.

The Scheldt process was a novel modality of transboundary diplomacy: an environmentalist-instigated multi-stakeholder model of negotiation, in which conservationist NGOs, cities, provinces and Flemish authorities had a say in long-term river planning. However, Islam and Susskind (2012) maintain a multitude of actors at the table also complicates negotiations. For Belgium, the multiparty visioning process the Dutch insisted on made things take way too long, feeding a latent suspicion that the Dutch, as in all earlier rounds, see Antwerp's growth as unfavourable to them, promoting delay tactics. The increasing Dutch Realpolitik leanings of the day only reinforced these misgivings. In 2010 a domestic Dutch populist wave manifested at the European stage as a readiness to ignore treaties for the sake of self-interest. Belgium's response was tit-for-tat: if you won't play nice, neither will we. But they had to await the government coalition's dissolution for a U-turn to be feasible. And the story is not over: the Antwerp harbour CEO alluded to the next round of deepening, and as a result, likely confrontation on the Scheldt during the heyday of Dutch Realpolitik right after dredging works for deepening in $2010^{10}$.

The power dynamics in Yemen stem from the way history and state formation shaped a country with a traditional tribal structure. This is reflected in pluriform sources of law impacting on water related conflicts and the way in which negotiation is dealt with in practice (Huntjens and De Man, 2014). In the tribal areas in northern and eastern

\footnotetext{
${ }^{10}$ E.g. https://www.tijd.be/ondernemen/transport/antwerpen-wil-nieuwe-s cheldeverdieping/9004493.html.
}

Yemen, sheikhs were traditionally selected based on heredity and acceptability within the tribe (Philips, 2011). As a consequence of the patronage system of former president Saleh, rent-seeking groups were formed stimulating nepotism and corruption. While Yemen's legal pluriformity is sufficiently known, a systematic identification of the different kinds of power and strength of the parties in disputes have not received adequate attention. The Yemeni case illustrates that institutions and better arguments do not necessarily win out while different sources of power are mobilised (proposition two). A lack of institutional authority ('bear') was offset by brutal upstream intervention ('lion'). States may endeavour to instrumentalise countervailing power animals, but these may prove weak or have their own agendas. In the Yemen case sources of authority mobilised (bears) proved weak or to go their own way.

The paradigm lenses and 'power animals' enable us to identify additional insights about actors' preferred styles of hydrodiplomatic negotiation, which otherwise would not be put forward in a structured manner. We hope that this approach contribute to the recognition of the role power plays in diplomacy and gain practical relevance in negotiations, and potentially prove beneficial to the analysis of negotiations in other environmental domains.

\section{Author statement}

While the original impetus came from Jeroen Warner, both authors have roughly equally contributed to the analysis, write-up and revisions. Jeroen Warner is responsible for the Scheldt case, Rens de Man for the Yemen case. Rens also crafted the Figures.

\section{Declaration of Competing Interest}

The authors declare that they have no known competing financial interests or personal relationships that could have appeared to influence the work reported in this paper.

\section{References}

Strauss, M., de La Hamaide, S., 2020. Belgium Blames France After Finding Tonnes of Dead Fish in River. Reuters. Online: https://www.reuters.com/article/us-france-b elgium-pollution/belgium-blames-france-after-finding-tonnes-of-dead-fish-in-riveridUSKBN22C3IA Accessed 29 July 2020.

Adler-Nissen, R., Pouliot, V., 2014. Power in practice: negotiating the international intervention in Libya. Eur. J. Int. Relat. 20 (4), 889-911.

Allan, J.A., Mirumachi, N., 2010. Why negotiate? Asymmetric endowments, asymmetric power and the invisible nexus of water, trade and power that brings apparent water security. In: Earle, A., Jägerskog, A., Öjendal, J. (Eds.), Transboundary Water Management: Principles and Practice. Earthscan, Stockholm.

Axelrod, R., Keohane, R.O., 1985. Achieving cooperation under anarchy: strategies and institutions. World Polit. 38 (1), 226-254.

Barnes-Dabban, H., van Koppen, C.K., van Tatenhove, J.P., 2018. Regional convergence in environmental policy arrangements: a transformation towards regional environmental governance for West and Central African ports? Ocean Coast. Manag. $163,151-161$.

Brooks, P., 2011. The future of water. Foreign Policy 22 (March).

Bulloch, J., Darwish, A., 1993. Coming Conflicts-Water Wars in the Middle East. Victor Gollancz, London.

Buuren, Avan, Warner, J., 2009. Multi-stakeholder learning and fighting on the river Scheldt. Int. Negot. 14 (2), 419-440.

Criekemans, D., 2006. How subnational entities try to develop their own "Paradiplomacy": the case of Flanders (1993-2005). In: Paper Read at the Conference "Challenges for Foreign Ministries: Managing Diplomatic Networks and Optimizing Value'. 1 June 2006.

Criekemans, D., 2010. Regional Sub-state Diplomacy Today. Brill., Leiden.

Culpepper, P.D., 2002. Powering, puzzling, and' pacting': the informational logic of negotiated reforms. J. Eur. Public Policy 9 (5), 774-790.

De Jong, D., 2000. Nature conservation policy: transboundary arrangements. Political Modernisation and the Environment. Springer, Dordrecht, pp. 97-115.

De Man, R., 2016. Transboundary Wastewater Governance Between Israel and Palestine: Options Based on Uncertainty Identification, Working Paper 15. The Hague Institute.

Donahue, J., Johnson, B.R., 1997. Water, Culture, and Power: Local Struggles in a Global Context. Island Press.

Dore, J., 2007. Mekong region Water-related MSPs-unfulfilled potential. In: Warner, J. (Ed.), Multi-Stakeholder Platforms for Integrated Water Management. Ashgate, 205ff., Aldershot. 
Eliasson, J., 2015. The rising pressure of global water shortages. Nature News 517 (7532), 6.

Farnum, R.L., 2018. Drops of diplomacy: questioning the scale of hydrodiplomacy through fog-harvesting. J. Hydrol. (Amst) 562, 446-454.

Fisher, R., Ury, W.L., Patton, B., 2011. Getting to Yes: Negotiating Agreement Without Giving in. Penguin.

George, R., 1927. The Scheldt Dispute. Foreign Affairs, October 1927. Online: https ://www.foreignaffairs.com/articles/denmark/1927-10-01/scheldt-dispute.

Giordano, M., 2003. The geography of the commons: the role of scale and space. Annals of the Association of American Geographers 93 (2), 365-375.

Gupta, J., 2016. The watercourses convention, hydro-hegemony and transboundary water issues. International Spectator 11, 8-131. Online: https://www.tandfonline. $\mathrm{com} / \mathrm{doi} /$ full/10.1080/03932729.2016.1198558.

Haas, P.M., 1990. Saving the Mediterranean: the Politics of International Environmental Cooperation. Columbia University Press.

Hanna, R., Allouche, J., 2018. Water nationalism in Egypt: State-building, nation-making and nile hydro-politics. In: Menga, F., Swyngedouw, E. (Eds.), Water, Technology and the Nation-State. Routledge.

Haufler, V., 1993. Crossing the boundary between public and private. In: Rittberger, V. (Ed.), International Regimes and non-State Actors. Regime Theory and International Relations. Oxford University Press, pp. 94-111.

Heclo, H., 1974. Modern Social Politics in Britain and Sweden: From Relief to Income Maintenance. Yale University Press, New Haven, Conn.

Heller, K.J., 1996. Power, subjectification and resistance in foucault. SubStance 25 (1), 78-110.

Helmreich, J.E., 2019. Belgium and Europe: A Study in Small Power Diplomacy (Vol. 3). Walter de Gruyter.

Hocking, B., 2005. Rethinking the 'new' public diplomacy. The New Public Diplomacy. Palgrave Macmillan, London, pp. 28-43.

Hocking, B., 2006. 'Multistakeholder diplomacy': forms, functions and frustrations. In: Kurbalija, J., Katrandjiev, V. (Eds.), Multistakeholder Diplomacy: Challenges and Opportunities. Geneva: DiploFoundation; 2006., pp. 13-29.

Hoff, H., 2011. Understanding the Nexus: Background Paper for the Bonn2011 Conference.

Huntjens, P., De Man, R., 2014. The political economy of Water management in Yemen: conflict analysis and recommendations. Research Report for Netherlands Embassy in Yemen.

Huntjens, P., De Man, R., 2017. Water diplomacy: making Water cooperation work. In: Policy Brief, Planetary Security Initiative. April 2017.

Islam, S., Susskind, L.E., 2012. Water Diplomacy: a Negotiated Approach to Managing Complex Water Networks. Routledge.

Jarvis, T., Wolf, A.T., 2010. Managing water negotiations and conflicts in concept and in practice. In: Earle, A., Jägerskog, A., Öjendal, J. (Eds.), Transboundary Water Management: Principles and Practice, London. Earthscan, Washington, DC, pp. 125-141.

Jessop, B., 2002. Governance and Metagovernance: On Reflexivity, Requisite Variety, and Requisite Irony. Online:. Department of Sociology, Lancaster University, Lancaster, UK http://www.comp.lancs.ac.uk/sociology/papers/JessopGovernance -and-Metagovernance.pdf.

Jones, P., 2017. Track Two diplomacy and the JOCI project: some points to look for. In: Najem, T., Molloy, M.J., Bell, M.D., Bell, J. (Eds.), Track Two Diplomacy and Jerusalem: The Jerusalem Old City Initiative. Taylor \& Francis, pp. 11-33.

Julien, F., 2013. Explaining the persistent appeal of' water wars' scenarios. Global Water Forum, GWF Discussion Paper 1354.

Kelman, I., 2007. Disaster Diplomacy in the Asia-pacific Region. Disaster Reduction in Asia Pacific Issue 03, 2007 UN ISDR Infoms. Online: http://www.disasterdiplomacy. org/kelmanetal.ddisdr.pdf.

Kissinger, H., 1995. Diplomacy. Simon \& Schuster., New York.

Klimes, M., Michel, D., Yaari, E., Restiani, P., 2019. Water diplomacy: the intersect of science, policy and practice. Journal of Hydrology 575, 1362-1370.

Krasner, S.D. (Ed.), 1983. International Regimes. Cornell University Press, Ithaca, NY.

Kreutz, J., 2012. From tremors to talks: Do natural disasters produce ripe moments for resolving separatist conflicts? International Interactions 38 (4), 482-502.

Lowi, M.R., 1995. Water and Power: the Politics of a Scarce Resource in the Jordan River Basin (Vol. 31). Cambridge University Press.

Machiavelli, N., 1952. In: Fuller, N. (Ed.), The Prince, by N. Machiavelli, and Leviathan, Or, Matter, Form and Power of a Commonwealth Ecclesiastical and Civil, by T. Hobbes. Encyclopaedia Britannica.

Mattern, J.B., Zarakol, A., 2016. Hierarchies in world politics. International Organization 70 (3), 623-654.

McConnell, F., Moreau, T., Dittmer, J., 2012. Mimicking state diplomacy: the legitimizing strategies of unofficial diplomacies. Geoforum 43 (4), 804-814.

McCracken, M., Wolf, A.T., 2019. Updating the register of international river basins of the world. International Journal of Water Resources Development 35 (5), 732-782.

Meerts, P.W., 2014. Diplomatic Negotiation: Essence and Evolution. Department of Public International Law, Faculty of Law, Leiden University.

Meijerink, S., 2008. Explaining continuity and change in international policies. Issuelinkage, venue change and learning on policies for the river Scheldt estuary, 1967 2005. Environment and Planning A 40 (4), 848-866.

Meissner, R., 2005. Interest groups and the proposed Epupa Dam: towards a theory of water politics. Politeia 24 (3), 354-369.

Meissner, R., Warner, J., 2017. Hydro-hegemony or water security community? Collective action, cooperation and conflict in the SADC transboundary security complex. In: Suhardiman, D., Nicol, A., Mapedza, E. (Eds.), Water Governance and Collective Action: Multi-Scale Challenges. Routledge, pp. 46-57.
Menga, F., 2016. Domestic and international dimensions of transboundary water politics. Water Alternatives 9 (3), 704-723.

Mirumachi, N., Allan, J.A., 2007. Revisiting transboundary water governance: power, conflict cooperation and the political economy. In: Proceedings from CAIWA International Conference on Adaptive and Integrated Water Management: Coping With Scarcity. November, Basel, Switzerland.

Mitzen, J., 2006. Anchoring Europe's civilizing identity: habits, capabilities and ontological security. Journal of European Public Policy 13 (2), 270-285.

Philips, S., 2011. Yemen and the Politics of Permanent Crisis. Routledge, Oxford.

Pohl, B., Carius, A., Conca, K., Dabelko, G.D., Kramer, A., Michel, D., Schmeier, S., Swain, A., Wolf, A., 2014. The Rise of Hydro-diplomacy. Strengthening Foreign Policy for Transboundary Waters. adelphi, Berlin.

Poppo, L., Zhou, K.Z., Ryu, S., 2008. Alternative origins to interorganizational trust: an interdependence perspective on the shadow of the past and the shadow of the future. Organization Science 19 (1), 39-55.

Puchala, D.J., Hopkins, R.F., 1982. International regimes: lessons from inductive analysis. International organization 36 (2), 245-275.

Putnam, R.D., 1988. Diplomacy and domestic politics: the logic of two-level games. International Organization 42 (3), 427-460.

Ritchie, N.E., Egeland, K., 2018. 'The diplomacy of resistance: power, hegemony and nuclear disarmament. Global Change Peace \& Security 30 (2), 121-141. https://doi. org/10.1080/14781158.2018.1467393.

Ruggie, J.G., 2005. Modernists must take over the United Nations. Financial Times 24, 18.

Sadoff, C.W., Grey, D., 2002. Beyond the river: the benefits of cooperation on international rivers. Water policy 4 (5), 389-403.

Scott, J.C., 1985. Weapons of the Weak: Everyday Forms of Peasant Resistance. Yale University Press.

Scott, J., 2001. Power. Polity Press, Cambridge.

Scott, J., 2008. Modes of power and the re-conceptualization of elites. The Sociological Review 56 (1_suppl), 25-43.

Shapland, G., 1997. Rivers of Discord: International Water Disputes in the Middle East. C. Hurst \& Co.

Sharp, P., 2009. Diplomatic Theory of International Relations. Cambridge University Press, Cambridge, UK.

Stucki, P., 2005. Water wars or water peace? Rethinking the nexus between water scarcity and armed conflict. Programme for Strategic and International Security Studies-Graduate Institute of International Studies.

Suri, J., 2019. The Long Rise and Sudden Fall of American Diplomacy. Foreign Policy, April 17.

Teisman, G.R., 2000. Models for research into decision-making processes: on phases. Streams and Decision-Making Rounds" Public administration: journal of the Royal Institute of Public Administration 78 (4), 937-956.

Van Genderen, R., Rood, J., 2011. Water Diplomacy, a Niche for the Netherlands. Clingendael, Den Haag.

Verhallen, A., van Densen, W., 2012. Leerzame complexiteit. Debatteren en informeren over de toekomst van het Schelde-estuarium. Unpublished monograph.

Vij, S., Warner, J.F., Biesbroek, R., Groot, A., 2019. Non-decisions are also decisions: power interplay between Bangladesh and India over the Brahmaputra River. Water International 1-21. Accessible at. https://www.tandfonline.com/doi/full/10.1080/ 02508060.2018 .1554767$.

Viotti, P. R., \& Kauppi, M. V. (2019 \{1991\}). International relations theory. Rowman \& Littlefield.

von Benda-Beckmann, K., 1981. Forum shopping and shopping forums: dispute processing in a Minangkabau village in West Sumatra. The Journal of Legal Pluralism and Unofficial Law 13 (19), 117-159.

Warner, J., 1992. The Politics of Diversion - Bridging Troubled Water in the Middle East. Master's Thesis Submitted to the Department of International Relations. University of Amsterdam, Amsterdam, Netherlands.

Warner, J., 2012. Three lenses on water war, peace and hegemonic struggle on the Nile. International Journal of Sustainable Society 4 (1-2), 173-193.

Warner, J.F., van Buuren, A., 2016. Reframing long-term controversies in transboundary river management. The intermediate role of puzzling and powering in tackling wicked problems. Futures 76, 18-29.

Warner, J.F., Wester, P., Hoogesteger, J., 2014. Struggling with scales: revisiting the boundaries of river basin management. Wiley Interdisciplinary Reviews: Water 1 (5), 469-481.

Wendt, A., 1999. Social Theory of International Politics (Vol. 67). Cambridge University Press.

Wiseman, G., 2011. Bringing diplomacy back in: time for theory to catch up with practice. Int. Stud. Rev. 13 (4), 710-713.

Wolf, A.T., 1995. Hydropolitics Along the Jordan River: Scarce Water and Its Impact on the Arab-israeli Conflict (Vol. 99). United Nations University Press.

Zartman, W., 2001. All rights reserved. The timing of peace initiatives: hurting stalemates and ripe moments. Global Rev. Ethnop. 1 (1), 8-18.

Dr Jeroen Warner teaches, trains and publishes on Disaster Studies at Wageningen University, where he took his $\mathrm{PhD}$ degree in 2008 and is now senior Associate Professor. His main research interests in the disaster management domain are social resilience and participation, the politics of disaster risk reduction and urban disaster response. On that last theme, he coordinated the European Horizon 2020 Coordination and Support Action, EDUCEN, on cities, cultures and catastrophes, and won a CAPES scholarship as Special Visiting Professor at the University of Sao Paulo, Brazil. He was Wageningen coordinator in two Bangladesh-focused Integrated Projects funded by the Dutch Science Foundation: Dynamic Deltas and Hydrosocial Deltas. A founder member of the London Water Research Group, Dr Jeroen also works on domestic and transboundary water conflict, participatory 
resource management, and governance issues. He is Acting Editor-in-Chief of the International Journal of Water Governance and Regions and Cohesion, and an editor of Ambiente e Sociedade.

Rens W. de Man Over the last 20 years Rens de Man has built up broad professional experience as strategic advisor, researcher and project manager in varying international contexts. Mr De Man published and presented various papers at international conferences. He has a background in hydrology, social sciences and water diplomacy and gained a strong expertise in groundwater governance in Gujarat, India through his $\mathrm{PhD}$ research in India, which focused on the multilevel policy and institutional changes in groundwater governance. This research is being finalised. He is currently working at P2, a company specialised in complex transitions in land, water and energy systems. 